\title{
Postural characterization in visually impaired young adults: preliminary study.
}

\author{
Caracterização postural em deficientes visuais adultos jovens: estudo preliminar.
}

\author{
Graziela Morgana Silva Tavares ${ }^{(1)}$, Caroline Cunha do Espírito Santo(2), Thiele de Cássia Libardoni( ${ }^{(2)}$, Cristina \\ Maria Santos(3), Paula Martins Nunes(3), Larissa Sinhorim(3), Daniel Henrique Mota(5), Gilmar Moraes \\ Santos ${ }^{(6)}$. \\ Center of Health Sciences and Sports (CEFID), University of Santa Catarina State (UDESC), Florianópolis (SC), Brazil.
}

\begin{abstract}
Introduction: The postural control system, responsible for maintaining the erect posture, is a strongly influenced by the visual system. Posture is the state of balance between muscles and bones, capable of protecting other structures of the human body from possible injuries. The visual system plays an important role in stabilizing the posture by continuously provide, with respect to the current position and the segments of the body in relation to themselves and the environment information nervous system. Objective: Characterize postural profile of young adults with visual impairment using computerized photogrammetry. Methods: A postural analysis was performed in thirteen subjects 8 female and 5 male $(30.85 \pm 6.85$ years), by recording images of the anterior, posterior and lateral views. All data were analyzed using the SAPO postural assessment software and the results tabulated in Microsoft Office Excel 2007 program. Descriptive statistics were performed. Results: It was shown that the subjects in this study had the following changes in postural profile: forward head, torso leaning back, pelvic anteversion and valgus hindfoot. Conclusion: The findings of this study showed that the attitude of these individuals is characterized by forward head, posterior tilt of the trunk, anterior pelvic tilt, knees flexed and valgus hindfoot. Additionally, it appears that this quantitative and qualitative method, low cost, can easily be incorporated into the clinical setting, it is useful to health professionals in the identification of postural changes and consequently the most appropriate treatment for these individuals. Keywords: Visually impaired persons; Posture; Photogrammetry.
\end{abstract}

\section{Resumo}

Introdução: O sistema de controle postural, responsável pela manutenção da postura ereta, é fortemente influenciado pelo sistema visual. A postura é o estado de equilíbrio entre músculos e ossos, capazes de proteger as demais estruturas do corpo humano de possíveis traumatismos. O sistema visual desempenha um papel importante na estabilização da postura, por fornecer continuamente ao sistema nervoso, informação atualizada a respeito da posição e dos segmentos do corpo em relação a eles mesmos e ao ambiente. Objetivo: Caracterizar o perfil postural de indivíduos adultos jovem com deficiência visual utilizando-se da fotogrametria computadorizada. Método: Foi realizada uma análise postural em treze sujeitos 8 do gênero feminino e 5 masculino $(30,85 \pm 6,85$ anos), por meio do registro de imagens nas vistas anterior, posterior e lateral. Todos os dados foram analisados por meio do software de avaliação postural SAPO e os resultados tabulados no Programa Microsoft Office Excel 2007. Foi realizada estatística descritiva. Resultados: Foi evidenciado que os sujeitos do presente estudo apresentaram as seguintes alterações do perfil postural: anteriorização da cabeça, inclinação de tronco para trás, anteversão pélvica e valgismo de retropé. Conclusão: Os achados deste estudo evidenciaram que a postura desses indivíduos é caracterizada pela anteriorização da cabeça, inclinação posterior de tronco, anteversão pélvica, joelhos fletidos e retropé valgo. Adicionalmente, verifica-se que este método quantitativo e qualitativo, de baixo custo, pode facilmente ser incorporado no ambiente clínico, sendo útil aos profissionais da área da saúde na identificação de alterações posturais e em consequência no tratamento mais adequado para esses indivíduos.

Palavras chave: Pessoas com deficiência visual; Postura; Fotogrametria.

\section{Submission date 11 August 2014, Acceptance date 10 November 2014, Publication date 20 November 2014.}

1. MSc. teacher of Physical Therapy School at Federal University of Pampa (UNIPAMPA), Uruguaiana (RS), Brazil.

2. Physical Therapist; Masters in Physiotherapy, University of Santa Catarina State(UDESC), Florianópolis (SC), Brazil.

3. Physical Therapist; Students of Masters in Physiotherapy program, University of Santa Catarina State(UDESC), Florianópolis (SC), Brazil.

4. Physical Therapist, University of Santa Catarina State (UDESC), Florianópolis (SC), Brazil.

5. Physical Therapist, University of Santa Catarina State(UDESC), Itajaí (SC), Brazil.

6. Doctor teacher of Physical Therapy at University of Santa Catarina State(UDESC), Florianópolis (SC), Brazil.

\section{Corresponding Author:}

Graziela Morgana Silva Tavares - Address: BR 472 - Km 592 - Mailbox118 - Uruguaiana (RS), Brazil -Zip Code: 97500-970. - Phone: (55) 3413-4321 / (55) 3414-1484. - E-mail: grazielatavares@unipampa.edu.br - Financial support by CAPES The authors declares no conflicts of interest. 


\section{INTRODUCTION}

The American Academy of Orthopaedic defines posture as the equilibrium between muscles and bones, capable of protecting other structures of the human body to trauma, either while standing, sitting or lying down. ${ }^{(1)}$

The postural control system, responsible for maintaining the erect posture, is strongly influenced by the visual system.(2-5) This is responsible for informing the central nervous system the position of the head and body segments in relation to itself and the environment influencing the balance, coordination and posture. (6)

Considering that approximately $90 \%$ of the spatial information that we receive is visual source so, can be said, that the visual impairment interferes with posture making blind subjects unstable to the point of hindering the maintenance of upright posture. ${ }^{(6,7)}$

Some typical characteristics presented by the visually impaired, such as lack of spatial organization, disorganized body scheme and lack of initiative from the fear, insecurity and dependence, are capable of causing an impairment in the development of posture inducing the formation of a typical pathological postural pattern of this group. ${ }^{(8)}$

Some studies of congenital blind individuals, young adults and children, as evidenced the presence of persistent postural asymmetries, such as: Forward head, (812) shoulder asymmetry, previous weighbridge pelvis and spinal abnormalities. ${ }^{(11,13,14)}$

However, although there are evidences of postural changes found in patients with visual impairment in Brazil $(10,15)$ studies in the population of blind young adults are scarce. From this study, prevention projects and/or physiotherapy intervention for these individuals may be established in order to prevent and/or reduce deformities and bodily pains.

Given these considerations, the aim of this study was to characterize the posture in young adults blind.

\section{METHODS}

This study is characterized as being the cross-sectional follow-up descriptive and exploratory. It was approval by the ethics committee of the University of Santa Catarina State (protocol No. 19/2008).

The sample was composed of 13 blind subjects, 8 females and 5 males. The anthropometric data as well as the cause of visual loss and lateral preference are shown in Table 1.
To be included in the study subjects should be aged between 18 and 40 years old and presenting congenital or acquired blindness already diagnosed in the medical record belongs to the association, which were duly registered. Data were collected in August 2008 and were excluded from the study: pregnant, hearing and intellectually disabled, diabetics and amputees.

The instruments for the execution of the study was Styrofoam balls (15 $\mathrm{mm}$ and $24 \mathrm{~mm}$ ), dermatographic pencil, double sided tape, plumb bob, digital camera brand Mitsuca 8.0 megapixels, leveled tripod and digital scale Filizola ${ }^{\circledR}$ were used for the checking body mass and body height to check the balance used belongs to the stadiometer was used.

Postural assessment was performed by means of the postural assessment software (SAPO). ${ }^{(16)}$ This program assists in the diagnosis of the alignment of the body segments of an individual, establishing itself as an initial and follow-up for assessment and clinical treatment step. Angular measures for SAPO program and its validity and reliability were conducted by Braz et al. (17).

To obtain photos, the digital camera was positioned on a tripod with a height of $95 \mathrm{~cm}$ from the floor and at a distance of 3 meters from the subject.

The legs of the individuals were positioned in parallel at a distance of $10 \mathrm{~cm}$ demarcated on the ground due to tape embossed to facilitate recognition of the position by the blind. Beside the subject was placed a plumb line with two reflective balls having the distance of a ball other than 1 meter, it was used as a calibrator as the SAPO program protocol. Between the last point and the reflective marker calibrator had a distance of 50 centimeters.

On day of collection has been requested to the subjects who were in bathing suits and/or fitness for easy viewing and location of anatomical landmarks. After locating, marking each point with a dermatographic pencil was performed and on such points was fixed with double-sided tape, reflective markers, according to SAPO basic protocol. A table describing the anatomical points and angles and linear distance measures are available in Figure 1 .

In conjunction with postural assessment through SAPO qualitative clinical evaluation of posture in standing position was performed in study subjects.

All samples were previously scheduled with the subjects and was achieved in August 2008, at University of Santa Catarina State(UDESC) following order: rea-

Table1. Characterization of the sample consisted of 8 people females and 5 males (mean \pm standard deviation).

\begin{tabular}{|c|c|c|c|c|c|}
\hline $\begin{array}{l}\text { Subjects } \\
(n)\end{array}$ & Age (years) & Height (m) & Mass (kg) & Cause of visual impairment (n) & Lateral preference ( $n)$ \\
\hline 13 & $30.85 \pm 6.85$ & $1.58 \pm 0.07$ & $63.12 \pm 13.27$ & $\begin{array}{c}\text { Congenital (9) } \\
\text { Acquired (4) }\end{array}$ & $\begin{array}{l}\text { Right hand (11) } \\
\text { Left hand (1) } \\
\text { Both hands (1) }\end{array}$ \\
\hline
\end{tabular}

Subtitle: $\mathrm{m}=$ meters; $\mathrm{kg}=$ kilograms. 
ding and signed the informed consent for photographs, fill the Identification, acquisition of anthropometric data and images in the anterior, posterior and lateral right and left eye views.

During the data collection there was the control of noise and ambient temperature should be oscillating between $18^{\circ}$ and $23^{\circ} \mathrm{C}$. (18)

All data were analysed with SAPO and the results was tabulated in Microsoft Office Excel 2007 program and processed using descriptive statistics.

\section{RESULTS}

The means and standard deviations as well as the values of linear and angular distances variables are found in Table 2.

Postural changes in the qualitative analysis are displayed in Table 3.

\section{DISCUSSION}

The findings of this study show that blind individuals have adopted a characteristic posture behavior manifested by forward head, trunk tilt back, pelvic anteversion and valgus hindfoot. The results of the other variables not allowed to characterize a typical pattern, suggesting individualized and specific postural compensations.

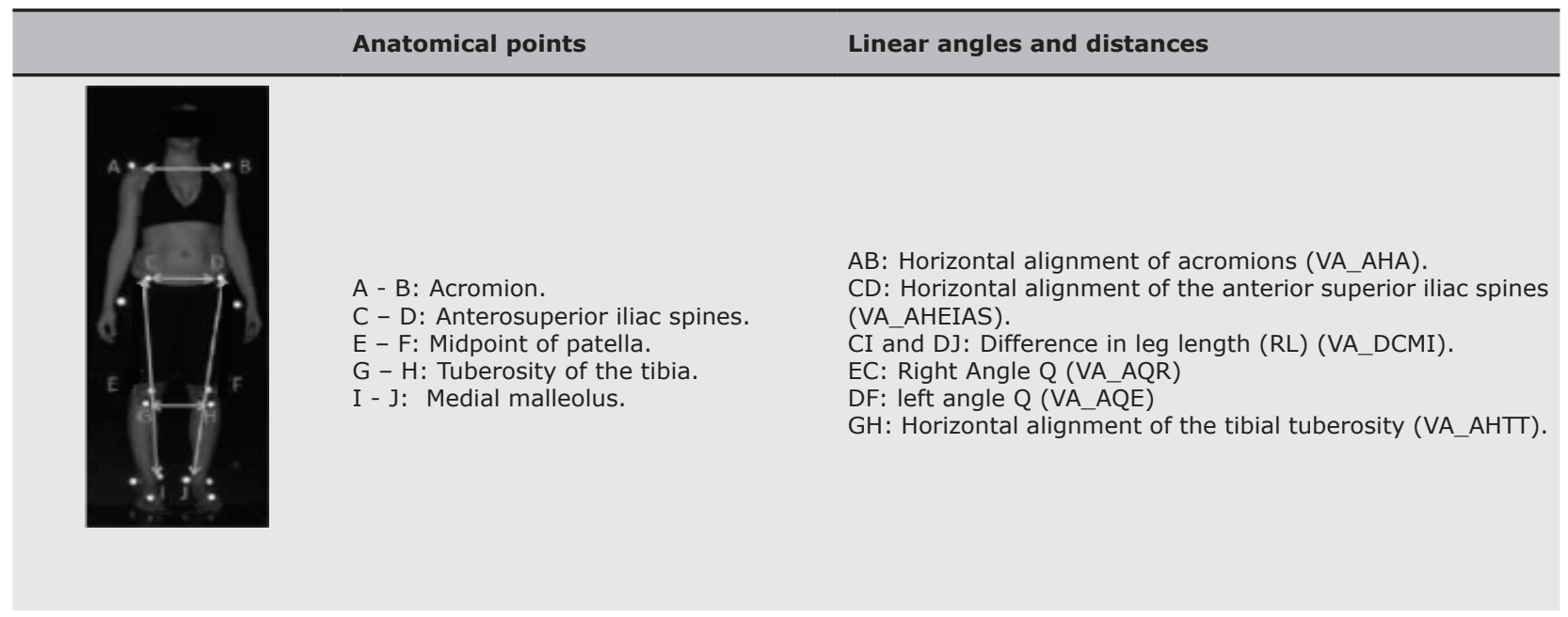

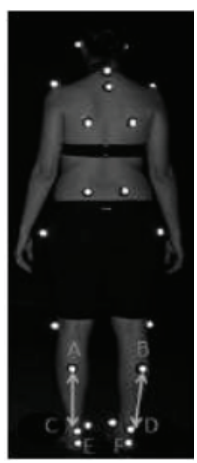

A - B: Point on the middle line.

C - D: Achilles Tendon.

E - F: Calcaneus.
ACE: Angle of leg / left hindfoot (VP_APRE). BDF: Angle of leg / right hindfoot (VP_APRD).

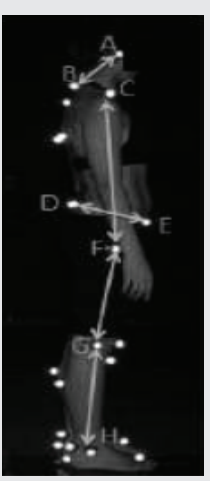

A: Tragus

B: Spinous process of the 7th cervical vertebra.

$A B$ : Horizontal alignment of head (VLAHC).

C: Acromion

DE: Horizontal alignment of pelvis (VL_AHP).

D: Posterior superior iliac spine.

CF: Vertical alignment of the trunk (VL_AVT).

$\mathrm{E}$ : Anterior superior iliac spine.

CFH: hip angle (VL AQ).

F: Greater trochanter

FGH: knee angle (VL_AJ).

G: Joint line of the knee.

$\mathrm{H}$ : Lateral malleolus.

Figure 1. anatomical points, angles and linear distances. 
Table 2. Angular and linear distances.

\begin{tabular}{|c|c|c|c|c|c|c|c|c|c|c|c|c|c|}
\hline \multirow{2}{*}{ Variables } & \multicolumn{13}{|c|}{ Individuals } \\
\hline & 1 & 2 & 3 & 4 & 5 & 6 & 7 & 8 & 9 & 10 & 11 & 12 & 13 \\
\hline \multicolumn{14}{|l|}{$\begin{array}{l}\text { Earlier } \\
\text { View }\end{array}$} \\
\hline VA_AHA & 3.6 & 1.3 & 3.5 & 0.8 & 4.2 & 6.3 & 2.4 & 2.5 & 6.3 & 2 & 4 & 1.7 & 2.2 \\
\hline VA_AHEIAS & 0.5 & 3.3 & 0.5 & 1.1 & 6.3 & 5.3 & 2.8 & 1.5 & 0.8 & 3.1 & 4.6 & 3.9 & 1.9 \\
\hline VA_DCMI & 0.2 & 0.8 & 0.6 & 0.7 & 2.4 & 1.8 & 0.4 & 0.2 & 1 & 1.9 & 3.1 & 0.1 & 0.6 \\
\hline VA_AHTT & 1.8 & 4.9 & 3.5 & 2 & 2.5 & 3.7 & 1.5 & 2 & 2.9 & 0.6 & 2.5 & 4.1 & 2 \\
\hline VA_AQD & 12.7 & 35 & 27.4 & 20 & 6.3 & 13.1 & 18.5 & 12.2 & 33.3 & 22 & 30.5 & 24.7 & 25.9 \\
\hline VA_AQE & 29.1 & 27.6 & 34.1 & 13.8 & 2 & 14.9 & 23 & 9.2 & 35.5 & 13.4 & 20.8 & 17.2 & 5.9 \\
\hline \multicolumn{14}{|l|}{$\begin{array}{l}\text { Later } \\
\text { View }\end{array}$} \\
\hline VP_APRD & 17.8 & 3 & 9.8 & 9.2 & 4 & 0.6 & 12 & 4.1 & 16.1 & 10.2 & 9.7 & 8.4 & 13.9 \\
\hline VP_APRE & 20.3 & 13.1 & 7.5 & 15 & 1.7 & 1.4 & 14.3 & 19.1 & 20.6 & 9.1 & 15.6 & 13.1 & 0.7 \\
\hline \multicolumn{14}{|l|}{$\begin{array}{l}\text { Side } \\
\text { View }\end{array}$} \\
\hline VL_AHC & 49.6 & 53.5 & 53.7 & 45 & 25.2 & 41 & 36.9 & 40.9 & 38.4 & 42.5 & 39.1 & 31.3 & 56.3 \\
\hline VL_AVT & 3.8 & 5.5 & 5.5 & 6.9 & 0.5 & 3.1 & 0.9 & 0.4 & 1.8 & 2.6 & 10.1 & 0.8 & 2.5 \\
\hline VL_AHP & 24.2 & 19.1 & 11.5 & 12.8 & 24.1 & 11.5 & 13.4 & 10.1 & 19.8 & 15.3 & 2.4 & 8.5 & 19.5 \\
\hline VL_AJ & 1.1 & 3.4 & 8.9 & 9.2 & 1.6 & 9.8 & 2.4 & 8.1 & 10 & 14.9 & 5 & 0.5 & 0.1 \\
\hline VL_AQ & 2.9 & 7.2 & 2.8 & 23.6 & 4.5 & 3.5 & 7 & 0.7 & 5 & 1.8 & 19.7 & -5 & 8.4 \\
\hline
\end{tabular}

SUbtitle: VA_AHA - Horizontal alignment of the acromial,VA_AHEIAS - Horizontal alignment of the anterior superior iliac spines, VA_DCMI - Difference in leg length (R-L), VA_AHTT - Horizontal alignment of the tibial tuberosity, VA_AQD - Right Q Angle, VA_AQE - Left Q Angle, VP_APRD - Angle leg / right hindfoot, VP_APRE - Angle leg /left hindfoot, VL_AHC - Horizontal alignment of the head, VL_AVT - vertical alignment of the trunk, VL_AHP - Horizontal alignment of the pelvis, VL_AJ - Knee Angle, VL_AQ - Hip angle.

Although a limited sample survey, it was observed that the characteristics of the head positioning of the blind individuals studied remained similar to those of other studies on the same subject, ${ }^{(8-12)}$ suggesting thereby that the blind can show clear postural changes in positioning of the head.

As noted by Rosen, (11) the forward head posture seen in the subjects of this study relates to a "protective stance" adopted to avoid collisions with objects. Salem et al. (19) also suggest that removing the visual stimulus has a significant effect on the position of the head since its orientation is when the individual looks at a distant point on the same horizontal plane at eye level.(20)

Another feature observed in all subjects was the asymmetry of the shoulder girdle, seen through the horizontal angle of acromia (VA_AHA). Since the highest acromion in all subjects was the left. However it has not been possible to correlate the causes of this asymmetry with those described in the literature, quote: Handedness, (21) scoliosis, (22) and increased muscle size of one side of the shoulder, triggered by the very activity developed by individual. (23)

So, it is believed that an accurate assessment regarding the use of cane field associated with the same check point could jointly or separately justify because of the asymmetry of the shoulder in order that the present study all subjects presented the contralateral limb elevated to the use of the cane. This way, may lead to com- 
Table 3. Postural changes through qualitative analysis.

\begin{tabular}{|c|c|c|}
\hline Region & Changes & $N(\%)$ \\
\hline \multirow{4}{*}{ Cervical } & Anteriorization head & $13(100)$ \\
\hline & Head turned to right & $9(6)$ \\
\hline & Head turned to the left & $4(3)$ \\
\hline & High left acromion & $13(100)$ \\
\hline \multirow{8}{*}{$\begin{array}{l}\text { Trunk and } \\
\text { pelvis }\end{array}$} & Lumbar hyperlordosis & $11(85)$ \\
\hline & Lumbar rectification & $2(15)$ \\
\hline & Thoracic kyphosis & $11(85)$ \\
\hline & Thoracic rectification & $2(15)$ \\
\hline & Scoliosis & $11(85)$ \\
\hline & Anterior pelvic tilt & $13(100)$ \\
\hline & $\begin{array}{l}\text { Anterior superior iliac spine high- } \\
\text { est right }\end{array}$ & $10(77)$ \\
\hline & $\begin{array}{l}\text { Anterior superior iliac spine high- } \\
\text { est left }\end{array}$ & $3(23)$ \\
\hline \multirow{11}{*}{$\begin{array}{l}\text { Lower } \\
\text { limbs }\end{array}$} & Hip flexion & $12(92)$ \\
\hline & Hip extension & $1(8)$ \\
\hline & Valgus knee & $12(92)$ \\
\hline & Varus knee & $1(8)$ \\
\hline & Pes planus & $13(100)$ \\
\hline & Right lower limb greater & $5(38)$ \\
\hline & Left lower limb greater & $8(62)$ \\
\hline & Tuberosity of the tibia highest right & $11(85)$ \\
\hline & Tuberosity of the tibia highest left & $2(15)$ \\
\hline & Knee flexion & $2(15)$ \\
\hline & Knee recurvatum & $11(85)$ \\
\hline
\end{tabular}

pensation for the misuse of the device. Entire route, this relationship was not performed in this study. It is then suggested an investigation of such cases.

In addition, the following changes was verified: Knee flexion in the standing position, observed average knee angle ( $\left.\mathrm{VL} \_\mathrm{AJ}\right)$ and trunk backward tilt, represented by the result of the vertical alignment of the trunk (VL_AVT), where eleven individuals (85\%) had lumbar hyperlordosis and hip flexion obtained by hip angle (VL_ $A Q)$. These results are consistent with the Rosen, ${ }^{(11)}$ who claim that blind children acquire postural deviations that are perpetuated into adulthood, due to the inability to learn the proper posture through visual limitations, as do the children seers.

By qualitatively analysis, it was found that all blind individuals studied had flat feet. To Bricot(21) flat feet is closely connected with valgus at the level of the subta- lar joint, the latter found in the population of visually impaired according to the results provided by SAPO through the leg/right hind and left angles (VP_APRD and VP_ APRE). Scranton et al,(24)justifying the presence of flat feet due to enlargement of the base during gait and poor development of posture commonly found in individuals with visual impairments.

The fall of the medial longitudinal arch also carries medial tibial and femoral rotations predisposing one knee and valgus displacement of patella. (21) According to Prentice, ${ }^{(25)}$ valgus enhances lateral movement of the patella during dynamic activities such as gait. Therefore, the $\mathrm{Q}$ angle measurement, even performed in static posture, provides important information about the position of the patella in relation to the femur. In this research, the average $Q$ angles (VA_AQD and VA_AQE) exceeded the value preset by SAPO, with the average ranging from $21.66^{\circ}$ to $18.96^{\circ}$, reinforcing the results of the qualitative evaluation of valgus of the right knee and left, respectively. These results differ from those found by Lima et al (15) to analyze the $\mathrm{Q}$ angle in the visually impaired, the obtained value of approximately 15 - However divergent results may be related to methodological differences between the current study and the above, such as the change of gender and the degree of visual impairment.

The result of the horizontal alignment of the pelvis (VL_AHP) and qualitative postural assessment revealed the presence of pelvic anteversion in all individuals analyzed. In the frontal plane, a pelvic height differences, obtained through the horizontal alignment of the anterior superior iliac spines (VA_AHEIAS) variable was also observed, with the highest that the left and right pelvis. This asymmetry is usually linked to the apparent discrepancy of the lower limbs, where the leg longer matches the higher iliac spine, ${ }^{26,27)}$ as the results of the variable length of the lower limbs (VA_DCMI) and horizontal alignment of the tibial tuberosity (VA_ATT) in this study.

\section{CONCLUSION}

This study was designed to measure postural profile visually impaired young adults. The findings of this study showed a posture characterized by forward head, posterior trunk tilt, pelvic anteversion, valgus rearfoot and knee flexed reflexes. Additionally, it appears that this quantitative and qualitative method, low cost, can easily be incorporated into the clinical setting, it is useful to health professionals in the identification of postural changes and consequently the best treatment to the subjects.

\section{REFERENCES}

1. Braccialli LMP, Vilarta R. Aspectos a serem considerados na elaboração de programas de prevenção e orientação de problemas posturais. Rev. paul. educ. fís.[Internet]. 2000 [acesso em 09 set 2009];14(2):159-70. Disponível em: http://www.portalsaudebrasil.com/artigospsb/reumato092.pdf. 
2. Mochizuki L, Amandio AC. As informações sensoriais para o controle postural. Fisioter. mov.[Internet]. 2006 [acesso em 31 mai 2010];19(2):11-8. Disponível em:http://www2.pucpr.br/reol/index.php/RFM?dd1=517\&dd99=view.

3. Shumway CA, Woollacott MH.Controle Motor:Teoria e aplicações práticas. 2a ed. São Paulo: Manole, 2003.

4. Lord SR, Menz HB. Visual contributions to postural stability in older adults. Gerontology. 2000;46(6):306-10. doi: 10.1159/000022182. PubMed PMID: 11044784.

5. Paulus W, StraubeA, Brandt T. Visual Stabilization of posture physiological stimulus characteristics and clinical aspects. Brain.1984;(107)4:1143-1163. doi: 10.1093/brain/107.4.1143

6. Cohen HS. Neurociência para fisioterapeutas:incluindo correlações clínicas. 2a ed. São Paulo: Manole, 2001.

7. Nakata H, Yabe K. Automatic postural response systems in individuals with congenital total blindness. Gait posture. 2001;(14)1:36-43. doi: 10.1016/S0966-6362(00)00100-4.

8. Rocha MCNR, Nogueira VC, Martins M, Pacheco MTT, Carvalho RA. Análise das Alterações Posturais Encontradas em Portadores de Deficiência Visual. In: Encontro Latino Americano de Iniciação Científica: São Paulo: 2008.

9. Mascarenhas CHM, Sampaio LS, Reis LA, Oliveira TS. Alterações posturais em deficientes visuais no município de Jequié/ BA. Revista Espaço para a Saúde [Internet]. 2009 [acesso em 27 jan 2010];(11)1: 1-7. Disponível em: http://www.ccs.uel.br/espacoparasaude/v11n1/alteracao.pdf

10. Sanchez HM, Barreto RR, Barauna MA, Canto RST, Morais EG. Avaliação postural de indivíduos portadores de deficiência visual através da biofotogrametria computadorizada. Fisioter. mov.[Internet]. 2008 [acesso em 09 set 2009];(21)2:11-20. Disponível em: www2.pucpr.br/reol/index.php/RFM?dd1=1934\&dd99=pdf.

11. Rosen S. Kinesiology an sensorimotor function. In: Blasch BB, Wiener WR, Welsh RL. Foundations of orientation and mobility. New York: AFB Press; 1997. p. 170-199.

12. FjellvangH, Solow B. Craniocervical postural relations and craniofacial morphology in 30 blind subjects. Am. J. Orthod. dentofacial orthop. 1986;(90)4:327-34. PubMed PMID: 3464194.

13. Catanzariti JF, Salomez E, Bruandet JM, Tevenon A.Visual deficiency and scoliosis. Spine J. 2001;(26)1:48-52.

14. Aulisa L, Bertolini C, Piantelli S, Piazzini DB. Axial deviations of the spine in blind children. Italian J. orthop. traumatol. 1986;12(1):85-92.

15. LimaRA, Passerini DK, Mello DGB, Martins RB, Magalhães AT, Medeiros VN. Avaliação postural em um grupo de deficientes visuais freqüentadores de um lar escola no município de Bauru-SP. In: 3a Jornada de Ciências da Saúde: São Paulo: 2008.

16. Portal do projeto software para avaliação postural - SAPO [internet]. São Paulo, SP: Incubadora virtual FAPESP [atualizada em jul. 2007; acesso em 12 set. 2009. Disponível em:http://sapo.incubadora.fapesp.br/portal/software.

17. Braz RG, Goes FPDC, Carvalho GA. Confiabilidade e validade de medidas angulares por meio do software para avaliação postural.Fisioter. Mov.[Internet]. 2008 [acesso em 17 jun 2009];(21)3:117-26. Disponível em: http:// www2.pucpr.br/reol/index.php/RFM?dd1=2073\&dd99=pdf

18. Pollock ML, Wilmore JH. Exercícios na saúde e na doença:avaliação e prescrição para prevenção e reabilitação. Rio de Janeiro: Medsi, 1993.

19. Salem $\mathrm{OH}$, Preston $\mathrm{CB}$. Head posture and deprivation of visual stimuli. Am. orthoptic j.[Internet]. 2002 [acesso em 03 jul 2009];52(1):95-103. Disponível em: http://aoj.uwpress.org/content/52/1/95.full.pdf+html.

20. Lundström A, Lundström F, Lebret LML, Moorrees CFA. Natural head position and head orientation: basic considerations in cephalometric analysis and research. Eur. J. Orthod.1995;(17)2:111-20.

21. Bricot B. Posturologia. São Paulo: Ícone; 2004.

22. Marques AP. Escoliose tratada com Reeducação Postural Global. Rev. Fisioter. Univ. São Paulo.[Internet]. 1996 [acesso em 10 set 2009];3(1/2):65-8. Disponível em: http://www.portalsaudebrasil.com/artigospsb/escolioserpg.pdf.

23. Fornasari CA. Repensando a clássica avaliação postural. Fisioter. Mov.1994;(6)2:40-53.

24. Scranton PE, Clark MW, McClosky SJ. Musculoskeletal problems in blind children. J. Bone Jt. Sur. Ser. A. 1978;(60)3:363-5. PubMed PMID: 649640.

25. Prentice WE. Técnicas de reabilitação em medicina esportiva. São Paulo: Manole, 2002.

26. Hoppenfeld S. Propedêutica ortopédica: coluna e extremidades. São Paulo: Atheneu; 1996.

27. Kendall FP, McCreary EK, Provance PG. Músculos: provas e funções, com postura e dor. São Paulo: Manole; 1995. 